\title{
Analisis Risiko dan Mitigasi Risiko pada Mebel Abi Rodim dengan Menggunakan Metode FMEA dan TOPSIS
}

\author{
Khalid Jundi Rabbani ${ }^{* 1}$, Syamsyudin Kameswara ${ }^{2}$, Fernando Alexander Fermi \\ Sitohang ${ }^{3}$, Nadya Farah Maghdalena ${ }^{4}$, Anggriani Profita ${ }^{5}$, dan Deasy Kartika Rahayu \\ Kuncoro ${ }^{6}$ \\ 1, 2, 3, 4, 5 Program Studi Teknik Industri, Fakultas Teknik, Universitas Mulawarman, Jl. Sambaliung No.9 Kampus \\ Gunung Kelua, Samarinda, 75119, Indonesia \\ ${ }^{6}$ Departemen Teknologi Industri Pertanian, Fakultas Teknologi Pertanian, IPB University, Jl. Kamper Kampus \\ IPB Darmaga, Bogor \\ Email: khalidjrabbani@gmail.com ${ }^{1}$, kameswara186@gmail.com², Fernandoalexander93@ gmail.com³ \\ nadyafarahmaghdalena@gmail.com ${ }^{4}$,profita@ft.unmul.ac.id ${ }^{5}$, kuncorodeasy@apps.ipb.ac.id ${ }^{6}$
}

\begin{abstract}
Abstrak
Mebel Abi Rodim merupakan usaha yang bergerak di bidang pembuatan perabotan rumah tangga seperti kursi, jendela, dan pintu. Manajemen risiko pada penelitian ini dilakukan untuk mengidentifikasi, menganalisis, dan mengendalikan faktor risiko pada kecelakaan kerja yang terjadi di Mebel Abi Rodim. Metode yang digunakan adalah FMEA dan TOPSIS. Berdasarkan hasil identifikasi terdapat enam kegiatan dengan 29 risiko kecelakaan yang kemudian ditentukan nilai kriteria severity, occurrence, dan detection. Hasil pengolahan data dengan diagram pareto didapatkan $20 \%$ risiko kecelakaan prioritas, yaitu jari terjepit kayu, tangan terkilir saat memotong bahan, kelilipan serbuk material, tangan terkena alat pemotong, tangan terkena permukaan bahan yang kasar saat mengambil bahan, dan tangan terkena permukaan bahan yang kasar saat memotong bahan. Akar-akar masalah tersebut diidentifikasi menggunakan diagram Ishikawa. Dari diagram Ishikawa, diperoleh opsi mitigasi risiko, kemudian digunakan metode TOPSIS untuk menentukan mitigasi risiko terbaik dan diperoleh alternatif solusi terbaik untuk risiko kecelakaan adalah memberikan Standar Operasional Prosedur penggunaan Alat Pelindung Diri dengan nilai RPI tertinggi, yaitu sebesar 0,853.
\end{abstract}

Kata kunci: FMEA, TOPSIS, Kecelakaan Kerja, Manajemen Risiko.

\section{Abstract}

Abi Rodim Furniture is a manufacturing company of furniture products such as chairs, windows, and doors. Risk management in this research aims to identify, analyze, and control the risk factors of work accidents at Abi Rodim's furniture. The methods used are FMEA and TOPSIS. Based on the identification results, there are six activities with 29 accident risks to determine criteria for severity, occurrence, and detection values. The results of using the Pareto diagram obtained $20 \%$ of the risk of priority accidents. These risks are fingers pinched by wood, sprained on the hands when cutting material, twisting of powder material, hands are hit by cutting tools, hands are exposed to rough material surfaces when taking material, and hands are exposed to rough surfaces when cutting material. These root causes of problems and risk mitigation options are identified and obtained using the Ishikawa diagram. TOPSIS method is used to determine the best risk mitigation. The best alternative solution for the risk of accidents is to provide Standard Operating Procedures for using Personal Protective Equipment with the highest RPI value, which is equal to 0,853 .

Keywords: FMEA, TOPSIS, Work accidents, Risk management.

\section{Pendahuluan}

Setiap proses produksi memiliki risiko kecelakaan kerja karena adanya kondisi yang tidak aman ataupun perbuatan yang tidak aman dari manusia itu sendiri. Perlunya identifikasi risiko kecelakaan kerja yang dapat terjadi sehingga akan lebih mudah dalam melakukan pencegahan kecelakaan kerja. Pada proses produksi pembuatan kusen, jendela, pintu, dan lain-lain di Mebel Abi Robim, Tenggarong Seberang, Kalimantan Timur seringkali tenaga kerja kurang hatihati dalam melakukan pekerjaan dan berpotensi membahayakan kesehatan dan keselamatan kerjanya.
Dampak bahaya yang terjadi biasanya seperti memar, mata merah, nyeri otot ringan, jari patah, tulang bergeser, keram ringan, mengganggu pendengaran, dan mengganggu pernafasan. Oleh karena itu, untuk mencegah terjadinya kecelakaan dan timbulnya biaya yang tinggi akibat risiko tersebut, maka diperlukan evaluasi dan analisis risiko untuk memperbaiki hal-hal tersebut.

Mitigasi risiko penting untuk dilakukan agar dapat menyelesaikan risiko-risiko yang dapat timbul, tindakan pencegahan yang diberikan dapat meminimalkan kerugian yang mungkin diterima oleh 
industri (Hendradewa \& Ma'arij, 2021). Mitigasi risiko merupakan upaya untuk menghindari atau mengurangi risiko kecelakaan kerja yang dapat terjadi, berbagai upaya yang dapat dilakukan adalah seperti memberikan pelatihan alat produksi pada pekerja, memperketat peraturan, atau hal-hal administrasi lainnya, penggunaan APD (alat pelindung diri), dan perbaikan lingkungan sekitar (sirkulasi udara dan pencahayaan) (Perdana \& Yuliawarti, 2014). Upaya pencegahan atau perbaikan untuk mengurangi risiko kecelakaan kerja perlu dilakukan agar proses produksi dapat berjalan dengan lancar dan mengurangi kerugian.

Penelitian pada Mebel Abi Rodim ini dilakukan untuk mengetahui risiko kecelakaan yang potensial yang terjadi pada proses pembuatan kusen, jendela, pintu, dan lain-lain serta menentukan solusi pencegahan terbaik dari risiko kecelakaan tersebut. Dengan penerapan metode Failure Mode Effect and Analysis (FMEA) dan Technique for Order Preference by Similarity to Ideal Solution (TOPSIS) maka akan dapat menyelesaikan masalah yang terjadi. Metode FMEA dipilih karena dapat mengidentifikasikan dan menilai setiap risiko kegagalan dari awal proses kerja atau produksi hingga selesai yang mana sesuai dengan penelitian di Mebel Abi Rodim ini. Metode TOPSIS dipilih karena dapat digunakan sebagai solusi pengambilan keputusan dalam menentukan alternatif mitigasi terbaik berdasarkan kriteria-kriteria yang ada dengan penerapan yang sederhana.

\section{Metode Penelitian}

Penelitian yang dilakukan pada mebel Abi Rodim yang berada di Tenggarong Seberang, Kalimantan Timur ini memanfaatkan metode Failure Mode Effect and Analysis (FMEA) dan Technique for Order Preference by Similarity to Ideal Solution (TOPSIS) dengan tambahan penggunaan tools diagram pareto dan diagram ishikawa agar dapat mengetahui risiko kecelakaan potensial yang terjadi pada proses pembuatan mebel dan solusi pencegahan terbaik dari risiko kecelakaan potensial tersebut.

\subsection{Manajemen Risiko}

Manajemen risiko adalah suatu proses untuk mengukur atau menilai seberapa besar risiko yang terjadi serta pengembangan strategi pengelolaannya. Terdapat beberapa strategi dalam pengelolaan risiko antara lain adalah memindahkan risiko kepada pihak lain, meghindari risiko, mengurangi dampak negatif risiko, dan menampung sebagian atau semua akibat suatu risiko tertentu. Manajemen risiko bertujuan untuk mengelola risiko sehingga organisasi dapat bertahan, atau dapat mengoptimalkan risiko ketidakpastian (Perdana \& Yuliawati, 2014).

\subsection{Failure Mode Effect and Analysis (FMEA)}

Failure Mode and Effect Analysis (FMEA) adalah suatu metode untuk menganalisis potensi masalah yang tidak diinginkan atau kegagalan dari suatu proses di awal siklus pengembangan yang lebih mudah untuk mengambil tindakan dalam mengatasi masalah, sehingga hanya perlu meningkatkan kehandalan melalui desain. FMEA diterapkan agar dapat mengidentifikasi bentuk potensi kegagalan yang kemudian ditentukan dampak dari kegagalan yang terjadi dan menentukan tindakan pencegahan untuk mengurangi kegagalan (Perdana \& Yuliawati, 2014).

Pada metode FMEA terdapat perhitungan yang perlu dilakukan jika ingin menentukan prioritas dari risiko-risiko yang telah diidentifikasi, yaitu perhitungan untuk mendapatkan nilai Risk Priority Number (RPN). Nilai RPN digunakan untuk mengetahui risiko mana yang perlu diprioritaskan untuk ditindak lanjuti dimana risiko dengan nilai RPN tertinggi menjadi prioritas (Pasaribu, et al., 2017).

$$
R P N=\text { Severity } x \text { Occurrence } x \text { Detection }
$$

Berikut merupakan kriteria keparahan (severity) untuk penilaian risiko yang dapat dilihat pada Tabel 1 .

Tabel 1. Severity

\begin{tabular}{|c|c|c|}
\hline Tingkat & Dampak & Akibat luka \\
\hline 10 & $\begin{array}{l}\text { Kehilangan nyawa } \\
\text { atau mengubah }\end{array}$ & $\begin{array}{l}\text { Kematian beberapa individu } \\
\text { (masal) }\end{array}$ \\
\hline 9 & kehidupan individu & Kematian satu individu \\
\hline 8 & & $\begin{array}{l}\text { Perlu penanganan serius dan } \\
\text { berakibat cacat permanen }\end{array}$ \\
\hline 7 & $\begin{array}{l}\text { Berdampak besar } \\
\text { pada individu } \\
\text { sehingga tidak } \\
\text { dapat ikut lagi } \\
\text { dalam aktivitas }\end{array}$ & $\begin{array}{l}\text { Dirawat lebih dari } 12 \text { jam, } \\
\text { dengan luka pecah } \\
\text { pembuluh darah, hilang } \\
\text { ingatan hebat, kerugian } \\
\text { besar, dll. }\end{array}$ \\
\hline 6 & & $\begin{array}{l}\text { Dirawat lebih dari } 12 \text { jam, } \\
\text { dengan patah tulang, tulang } \\
\text { bergeser, luka bakar, sulit } \\
\text { bernafas, dan hilang ingatan } \\
\text { sementara }\end{array}$ \\
\hline 5 & $\begin{array}{l}\text { Berdampak sedang } \\
\text { pada individu } \\
\text { hanya } 1 \text { sampai } 2\end{array}$ & $\begin{array}{l}\text { Keseleo, terkilir, cedera otot, } \\
\text { tulang retak, patah ringan, } \\
\text { keram, atau kejang }\end{array}$ \\
\hline 4 & $\begin{array}{l}\text { hari tidak dapat ikut } \\
\text { dalam aktivitas }\end{array}$ & $\begin{array}{l}\text { Luka bakar ringan, } \\
\text { luka gores atau } \\
\text { teriris, frosnip } \\
\text { (radang dingin atau } \\
\text { panas) }\end{array}$ \\
\hline 3 & $\begin{array}{l}\text { Berdampak kecil } \\
\text { pada individu dan }\end{array}$ & $\begin{array}{l}\text { Melepuh, tersengat panas, } \\
\text { keseleo ringan }\end{array}$ \\
\hline 2 & $\begin{array}{l}\text { masih dapat ikut } \\
\text { dalam aktivitas }\end{array}$ & $\begin{array}{l}\text { Tersengat matahari, memar, } \\
\text { teriris atau tergores ringan }\end{array}$ \\
\hline 1 & $\begin{array}{l}\text { Tidak berdampak } \\
\text { pada individu } \\
\text { (tidak mendapat } \\
\text { dampak yang } \\
\text { terasa) }\end{array}$ & $\begin{array}{l}\text { Terkena serpihan, tersengat } \\
\text { serangga, gatal ringan }\end{array}$ \\
\hline
\end{tabular}

Sumber: Wang, et al., 2009 (dikutip dari Pasaribu, et al., 2017) 
Berikut merupakan kriteria kejadian (occurrence) untuk penilaian risiko yang dapat dilihat pada Tabel 2 .

Tabel 2. Occurrence

\begin{tabular}{llc}
\hline \multicolumn{1}{c}{ Probabilitas kejadian } & Tingkat kejadian & Nilai \\
\hline Sangat tinggi dan tidak bisa dihindari & $>1$ in 2 & 10 \\
& 1 in 3 & 9 \\
Tinggi dan sering terjadi & 1 in 8 & 8 \\
& 1 in 20 & 7 \\
Sedang dan kadang terjadi & 1 in 80 & 6 \\
& 1 in 400 & 5 \\
Rendah dan relatif jarang terjadi & 1 in 2.000 & 4 \\
& 1 in 15.000 & 3 \\
Sangat rendah dan hampir tidak & 1 in 150.000 & 2 \\
Pernah terjadi & 1 in 1.500 .000 & 1 \\
\hline
\end{tabular}

Sumber: Wang, et al., 2009 (dikutip dari Pasaribu, et al., 2017)

Berikut merupakan kriteria deteksi (detection) untuk penilaian risiko yang dapat dilihat pada Tabel 3 .

Tabel 3. Detection

\begin{tabular}{clc}
\multicolumn{1}{c}{ Deteksi } & \multicolumn{1}{c}{ Kemungkinan Terdeteksi } & Ranking \\
\hline Hampir tidak & Tidak ada alat pengontrol saat ini & 10 \\
mungkin & $\begin{array}{l}\text { yang dapat mendeteksi bentuk dan } \\
\text { penyebab kegagalan }\end{array}$ & \\
Sangat & $\begin{array}{l}\text { Alat pengontrol saat ini hampir } \\
\text { tidak dapat mendeteksi bentuk dan }\end{array}$ & \\
jarang & $\begin{array}{l}\text { penyebab kegagalan } \\
\text { Alat pengontrol saat ini sangat sulit } \\
\text { Jarang }\end{array}$ & 8 \\
mendeteksi bentuk dan penyebab & \\
kangat & $\begin{array}{l}\text { Alat pengontrol memiliki } \\
\text { kemampuan sangat rendah dalam } \\
\text { mendeteksi bentuk dan penyebab } \\
\text { kegagalan }\end{array}$ & \\
Alat pengontrol memiliki \\
kemampuan rendah dalam \\
kendah
\end{tabular}

Sumber: Wang, et al., 2009 (dikutip dari Pasaribu, et al., 2017)

Ebrahemzadih et al (2014) menyatakan bahwa terdapat tingkat krisis untuk menyatakan pentingnya potensi atau risiko yang ada. Tingkat krisis terdiri dari tingkat normal, semi-kritis, dan kritis yang dijelaskan sebagai berikut:

1. Level Normal, dimana ketiga faktor RPN memiliki nilai kurang dari 5 atau angka RPN sangat rendah dan tidak memerlukan tindakan korektif atau preventif, namun tetap dapat dilakukan (RPN < 70),

2. Level Semi-Kritis, dimana setidaknya satu dari tiga faktor RPN memiliki nilai lebih besar dari 5 tetapi RPN relatif rendah, pada kasus ini tindakan korektif atau pencegahan sangat penting $(70<\mathrm{RPN}<140)$, dan

3. Level Kritis, dimana setidaknya dua dari tiga faktor RPN memiliki nilai tinggi atau nilai RPN terlalu tinggi sehingga jelas bahwa pada kasus ini harus memiliki tindakan korektif atau preventif (RPN > 140).

\subsection{Technique for Order Preference by Similarity to Ideal Solution (TOPSIS)}

Menurut Sachdeva et al (2009) dalam Perdana \& Yuliawati (2014) TOPSIS merupakan sebuah teknik untuk mengambil keputusan dengan memilih suatu alternatif berdasarkan jarak terpendek dengan titik ideal positifnya dan jarak terjauh dengan titik ideal negatifnya. Dalam menggunakan metode TOPSIS terdapat beberapa langkah yang perlu dilakukan, yaitu sebagai berikut:

1. Membentuk matriks perbandingan kriteria pada TOPSIS dengan persamaan:

$X=\left[x_{i j}\right]$

2. Menormalisasi matriks perbandingan kriteria dengan persamaan:

$r_{i j}=\frac{x_{i j}}{\sum_{i=1}^{n} x_{i j}}$

3. Menghitung bobot setiap perbandingan kriteria dengan persamaan:

$$
\begin{aligned}
& e_{j}=-\frac{1}{\ln n} \sum_{i=1}^{n} r_{i j} \ln r_{i j} \\
& w_{j}=\frac{1-e_{j}}{\sum_{j=1}^{m}\left(1-e_{j}\right)}
\end{aligned}
$$

4. Menetapkan solusi ideal positif $\left(\mathrm{v}^{+}\right)$dan solusi ideal negatif $\left(\mathrm{v}^{-}\right)$untuk setiap perbandingan kriteria dengan persamaan:

$$
\begin{aligned}
v^{+}= & \left(\max \left(r_{i 1}\right),\left(\max \left(r_{i 2}\right), \ldots,\right.\right. \\
& \left(\max \left(r_{i n}\right)\right) \\
= & \left(v_{1}^{+}, v_{2}^{+}, \ldots, v_{n}^{+}\right) \\
v^{-}= & \left(\min \left(r_{i 1}\right),\left(\min \left(r_{i 2}\right), \ldots,\right.\right. \\
& \left(\min \left(r_{i n}\right)\right) \\
= & \left(v_{1}^{-}, v_{2}^{-}, \ldots, v_{n}^{-}\right)
\end{aligned}
$$

5. Menghitung jarak setiap kriteria antara solusi ideal positif $\left(\mathrm{v}^{+}\right)$dan solusi ideal negatif $\left(\mathrm{v}^{-}\right)$ dengan persamaan: 


$$
\begin{aligned}
& d^{+}=\sqrt{\sum_{j=1}^{m} w_{j}\left(v_{j}^{+}-r_{i j}\right)^{2}} \\
& d^{-}=\sqrt{\sum_{j=1}^{m} w_{j}\left(r_{i j}-v_{j}^{-}\right)^{2}}
\end{aligned}
$$

6. Menghitung nilai Risk Priority Index (RPI) berdasarkan solusi ideal dengan persamaan:

$$
R P I=\frac{d_{i}^{-}}{d_{i}^{+}+d_{i}{ }^{-}}
$$

\subsection{Tahapan Penelitian}

Dalam penelitian ini, FMEA akan digunakan untuk mengidentifikasi risiko yang ada dan TOPSIS akan digunakan untuk pengambilan keputusan dalam memilih solusi alternatif. Dari penerapan metode FMEA nantinya akan didapatkan nilai RPN berdasarkan penilaian risiko $\mathrm{S}$ (Severity), $\mathrm{O}$ (Occurrence), dan D (Detection) yang dilakukan. Sedangkan dari penerapan metode TOPSIS nantinya akan didapatkan nilai RPI berdasarkan kriteria dalam pengambilan keputusan untuk mitigasi risiko.

Pada penelitian ini juga akan digunakan tools diagram Pareto untuk penentuan risiko yang potensial yang mungkin terjadi dengan aturan 80/20 akan dapat terlihat penyebab utamanya dari banyak kejadian (Satriyo \& Puspitasari, 2017). Tools lain yang akan digunakan adalah diagram Ishikawa atau yang biasa dikenal dengan nama diagram Fishbone (tulang ikan), diagram ini akan berguna untuk mengetahui sebab akibat suatu masalah dapat terjadi seperti masalah kualitas baik produk atau jasa dan masalah-masalah klasik di industri manufaktur (Mustofa, 2014).

Penelitian ini terdiri dari beberapa tahapan, yaitu tahap persiapan, tahap pengumpulan data, tahap pengolahan data, tahap analisis, dan penutup. Berikut ini dapat dilihat diagram alir penelitian pada Gambar 1 .

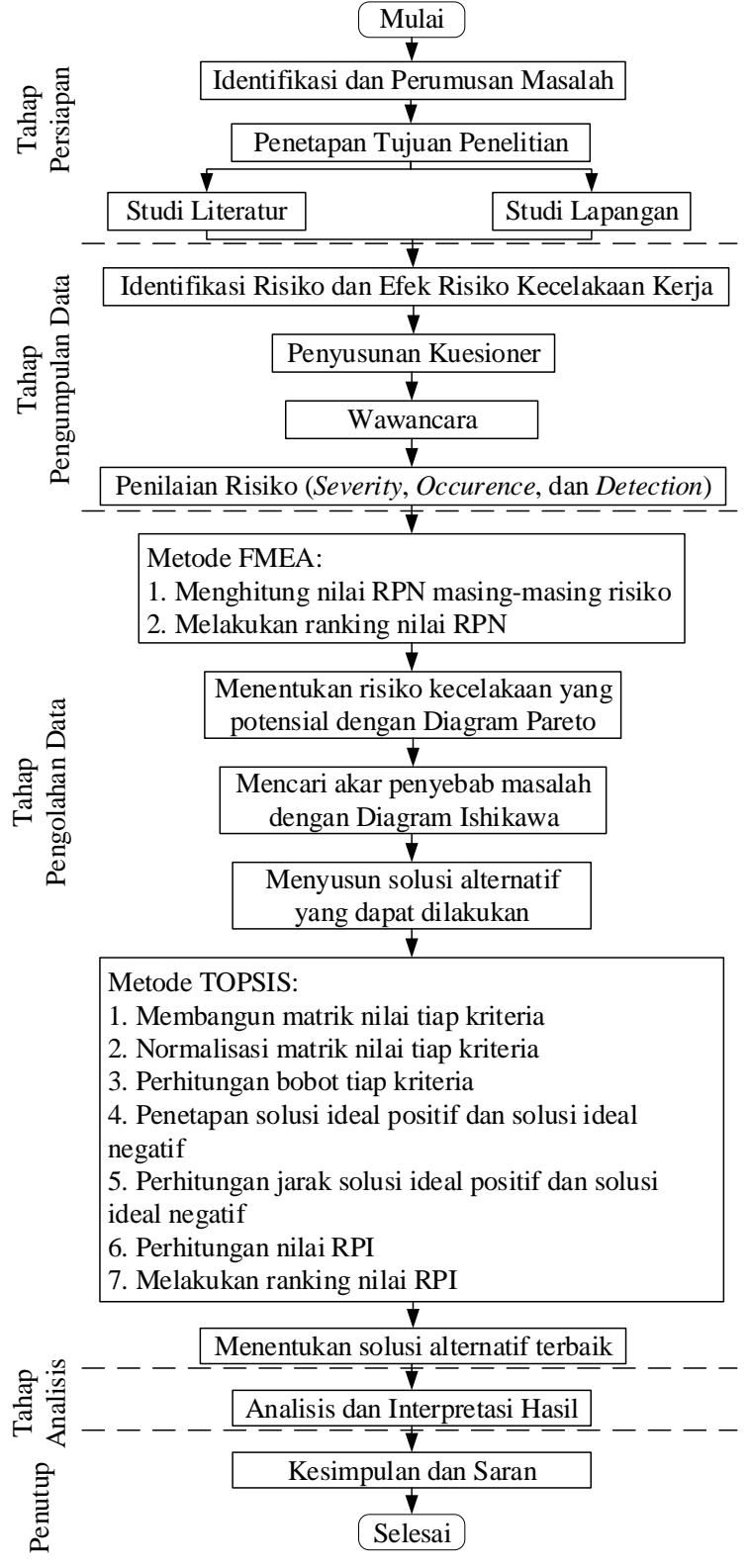

Gambar 1. Diagram Alir Penelitian

\section{Hasil dan Pembahasan}

Pada tahap awal dilakukan identifikasi risiko kecelakaan serta efek risiko yang terdapat pada proses pembuatan kusen, jendela, pintu di mebel Abi Rodim, Tenggarong Seberang, Kalimantan Timur. Pada pengerjaan kusen, jendela, dan pintu terdapat 6 kegiatan utama yaitu: pengambilan bahan baku, pemotongan atau pembelahan material, penghalusan permukaan material, pembentukan model (kusen, jendela, pintu, dan sebagainya), pelubangan, dan perakitan menjadi produk jadi. Dari hasil melakukan identifikasi 6 kegiatan utama tersebut terdapat 29 risiko kecelakaan kerja dan efek risiko kecelakaan kerja yang dapat dilihat pada Tabel 4 berikut: 
Tabel 4. Identifikasi Risiko Kecelakaan dan Efek Risiko

\begin{tabular}{|c|c|c|c|}
\hline Proses & & Risiko Kecelakaan & Efek Risiko \\
\hline \multirow[t]{6}{*}{$\begin{array}{l}\text { Pengambilan } \\
\text { bahan baku }\end{array}$} & $\mathrm{F} 1$ & $\begin{array}{l}\text { Tangan terkena } \\
\text { permukaan bahan } \\
\text { yang masih kasar } \\
\text { pada pengambilan } \\
\text { material (kayu, kaca) }\end{array}$ & $\begin{array}{l}\text { Terluka } \\
\text { ringan, memar } \\
\text { ringan }\end{array}$ \\
\hline & $\mathrm{F} 2$ & $\begin{array}{l}\text { Keseleo pada tangan } \\
\text { akibat pengangkatan } \\
\text { material }\end{array}$ & $\begin{array}{l}\text { Memar ringan, } \\
\text { nyeri otot } \\
\text { ringan }\end{array}$ \\
\hline & $\mathrm{F} 3$ & $\begin{array}{l}\text { Pinggang terkilir } \\
\text { akibat pengangkatan } \\
\text { material }\end{array}$ & $\begin{array}{l}\text { Memar ringan, } \\
\text { nyeri otot } \\
\text { ringan }\end{array}$ \\
\hline & $\mathrm{F} 4$ & $\begin{array}{l}\text { Kaki keseleo saat } \\
\text { pengangkatan } \\
\text { material }\end{array}$ & $\begin{array}{l}\text { Memar ringan, } \\
\text { nyeri otot } \\
\text { ringan }\end{array}$ \\
\hline & F5 & $\begin{array}{l}\text { Kaki tertimpa } \\
\text { material }\end{array}$ & $\begin{array}{l}\text { Memar berat, } \\
\text { patah } \\
\text { tulang, tulang } \\
\text { begeser }\end{array}$ \\
\hline & F6 & Jari terjepit kayu & $\begin{array}{l}\text { Memar berat, } \\
\text { Jari Patah, } \\
\text { tulang } \\
\text { bergeser }\end{array}$ \\
\hline \multirow[t]{7}{*}{$\begin{array}{l}\text { Pemotongan } \\
\text { atau } \\
\text { pembelahan } \\
\text { material }\end{array}$} & F7 & $\begin{array}{l}\text { Tangan terkena } \\
\text { permukaan bahan } \\
\text { baku yang masih } \\
\text { kasar pada saat } \\
\text { pemotongan } \\
\text { material }\end{array}$ & $\begin{array}{l}\text { Terluka } \\
\text { ringan, memar } \\
\text { ringan }\end{array}$ \\
\hline & F8 & $\begin{array}{l}\text { Tangan terkena alat } \\
\text { pemotong (gergaji, } \\
\text { gerinda) }\end{array}$ & Terluka ringan \\
\hline & F9 & $\begin{array}{l}\text { Suara alat pemotong } \\
\text { (gerinda) yang } \\
\text { mengganggu } \\
\text { pendengaran }\end{array}$ & $\begin{array}{l}\text { Mengganggu } \\
\text { pendengaran }\end{array}$ \\
\hline & F10 & $\begin{array}{l}\text { Kaki tertimpa } \\
\text { material pada saat } \\
\text { pemotongan material }\end{array}$ & $\begin{array}{l}\text { Memar ringan, } \\
\text { nyeri otot } \\
\text { ringan }\end{array}$ \\
\hline & F11 & $\begin{array}{l}\text { Terhirup serbuk } \\
\text { material (serbuk kayu, } \\
\text { kaca) hasil dari } \\
\text { pemotongan material }\end{array}$ & $\begin{array}{l}\text { Mengganggu } \\
\text { pernafasan }\end{array}$ \\
\hline & F12 & $\begin{array}{l}\text { Kelilipan serbuk } \\
\text { material (serbuk kayu, } \\
\text { kaca) hasil dari } \\
\text { pemotongan material }\end{array}$ & Mata merah \\
\hline & F13 & $\begin{array}{l}\text { Terkilir pada bagian } \\
\text { tangan saat } \\
\text { pemotongan material }\end{array}$ & Keram ringan \\
\hline \multirow[t]{2}{*}{$\begin{array}{l}\text { Penghalusan } \\
\text { permukaan } \\
\text { material }\end{array}$} & F14 & $\begin{array}{l}\text { Tangan terkena } \\
\text { permukaan bahan } \\
\text { baku yang masih } \\
\text { kasar (kayu, kaca) } \\
\text { pada proses } \\
\text { penghalusan material }\end{array}$ & $\begin{array}{l}\text { Terluka } \\
\text { ringan, memar } \\
\text { ringan }\end{array}$ \\
\hline & F15 & $\begin{array}{l}\text { Terhirup serbuk } \\
\text { material (serbuk kayu, }\end{array}$ & $\begin{array}{l}\text { Mengganggu } \\
\text { pernafasan }\end{array}$ \\
\hline
\end{tabular}

kaca) hasil dari proses penghalusan material

F16 Kelilipan serbuk material (serbuk kayu, kaca) hasil dari proses penghalusan material

F17 Terkilir pada bagian tangan pada saat penghalusan material

F18 Suara mesin (mesin

ketam) yang mengganggu pendengaran

Pembentukan F19 Tangan terkena alat Terluka ringan model pemotong pada (kusen, pembentukan pola jendela, pintu, dll.)

F20 Terkilir pada bagian tangan saat pembentukan pola

F21 Kaki tertimpa material pada saat pembentukan pola

Mata merah

Keram ringan

Mengganggu pendengaran

Keram ringan

Memar ringan, nyeri otot ringan

F22 Terhirup serbuk Mengganggu material (serbuk kayu, pernafasan kaca) hasil dari pembentukan pola

F23 Kelilipan serbuk material (serbuk kayu, kaca) hasil dari pembentukan pola

Pelubangan

F24 Tangan terkena alat pelubang (mesin bor) pada pelubangan material

F25 Terhirup serbuk Mengganggu material (serbuk kayu, pernafasan kaca) hasil dari pelubangan material

F26 Kelilipan serbuk Mata merah material (serbuk kayu, kaca) hasil dari pelubangan material

F27 Terkilir pada bagian tangan saat pelubangan material

Perakitan F28 Tangan terkena palu Memar ringan menjadi saat memaku produk jadi

F29 Tangan terkilir saat perakitan

Keram ringan

Risiko kecelakaan yang telah diidentifikasi kemudian digunakan sebagai variabel dalam wawancara lebih lanjut untuk mendapatkan nilai kriteria severity $(\mathrm{S})$, occurence $(\mathrm{O})$ dan detection $(\mathrm{D})$. Data kriteria tersebut dapat dilihat pada Tabel 5 berikut:

Tabel 5. Penilaian Risiko

\begin{tabular}{|c|c|c|c|c|c|}
\hline Proses & \multicolumn{2}{|r|}{ Risiko Kecelakaan } & $\mathrm{S}$ & $\mathrm{O}$ & $\mathrm{D}$ \\
\hline \multirow[t]{5}{*}{$\begin{array}{l}\text { Pengambilan bahan } \\
\text { baku }\end{array}$} & F1 & $\begin{array}{l}\text { Tangan terkena permukaan bahan yang } \\
\text { masih kasar pada pengambilan material } \\
\text { (kayu, kaca) }\end{array}$ & 4 & 8 & 1 \\
\hline & $\mathrm{F} 2$ & $\begin{array}{l}\text { Keseleo pada tangan akibat } \\
\text { pengangkatan material }\end{array}$ & 2 & 3 & 1 \\
\hline & F3 & $\begin{array}{l}\text { Pinggang terkilir akibat pengangkatan } \\
\text { material }\end{array}$ & 2 & 2 & 3 \\
\hline & $\mathrm{F} 4$ & Kaki keseleo saat pengangkatan material & 3 & 2 & 5 \\
\hline & F5 & Kaki tertimpa material & 6 & 1 & 5 \\
\hline
\end{tabular}




\begin{tabular}{|c|c|c|c|c|c|}
\hline & F6 & Jari terjepit kayu & 6 & 2 & 7 \\
\hline \multirow[t]{7}{*}{$\begin{array}{l}\text { Pemotongan atau } \\
\text { pembelahan material }\end{array}$} & F7 & $\begin{array}{l}\text { Tangan terkena permukaan bahan baku } \\
\text { yang masih kasar pada saat pemotongan } \\
\text { Material }\end{array}$ & 4 & 8 & 1 \\
\hline & F8 & $\begin{array}{l}\text { Tangan terkena alat pemotong (gergaji, } \\
\text { gerinda) }\end{array}$ & 2 & 5 & 4 \\
\hline & F9 & $\begin{array}{l}\text { Suara alat pemotong (gerinda) yang } \\
\text { mengganggu pendengaran }\end{array}$ & 1 & 9 & 1 \\
\hline & F10 & $\begin{array}{l}\text { Kaki tertimpa material pada saat } \\
\text { pemotongan material }\end{array}$ & 3 & 2 & 3 \\
\hline & F11 & $\begin{array}{l}\text { Terhirup serbuk material (serbuk kayu, } \\
\text { kaca) hasil dari pemotongan material }\end{array}$ & 3 & 7 & 1 \\
\hline & $\mathrm{F} 12$ & $\begin{array}{l}\text { Kelilipan serbuk material (serbuk kayu, } \\
\text { kaca) hasil dari pemotongan material }\end{array}$ & 3 & 7 & 1 \\
\hline & F13 & $\begin{array}{l}\text { Terkilir pada bagian tangan saat } \\
\text { pemotongan material }\end{array}$ & 3 & 5 & 3 \\
\hline \multirow[t]{5}{*}{$\begin{array}{l}\text { Penghalusan } \\
\text { permukaan material }\end{array}$} & F14 & $\begin{array}{l}\text { Tangan terkena permukaan bahan baku } \\
\text { yang masih kasar (kayu, kaca) pada } \\
\text { proses penghalusan material }\end{array}$ & 4 & 4 & 1 \\
\hline & F15 & $\begin{array}{l}\text { Terhirup serbuk material (serbuk kayu, } \\
\text { kaca) hasil dari proses penghalusan } \\
\text { Material }\end{array}$ & 3 & 7 & 1 \\
\hline & F16 & $\begin{array}{l}\text { Kelilipan serbuk material (serbuk kayu, } \\
\text { kaca) hasil dari proses penghalusan } \\
\text { Material }\end{array}$ & 3 & 7 & 1 \\
\hline & F17 & $\begin{array}{l}\text { Terkilir pada bagian tangan pada saat } \\
\text { penghalusan material }\end{array}$ & 3 & 2 & 3 \\
\hline & F18 & $\begin{array}{l}\text { Suara mesin (mesin ketam) yang } \\
\text { mengganggu pendengaran }\end{array}$ & 2 & 9 & 1 \\
\hline \multirow{5}{*}{$\begin{array}{l}\text { Pembentukan model } \\
\text { (kusen, jendela, } \\
\text { pintu, dll.) }\end{array}$} & F19 & $\begin{array}{l}\text { Tangan terkena alat pemotong pada } \\
\text { pembentukan pola }\end{array}$ & 2 & 4 & 4 \\
\hline & $\mathrm{F} 20$ & $\begin{array}{l}\text { Terkilir pada bagian tangan saat } \\
\text { pembentukan pola }\end{array}$ & 3 & 2 & 3 \\
\hline & $\mathrm{F} 21$ & $\begin{array}{l}\text { Kaki tertimpa material pada saat } \\
\text { pembentukan pola }\end{array}$ & 3 & 2 & 3 \\
\hline & $\mathrm{F} 22$ & $\begin{array}{l}\text { Terhirup serbuk material (serbuk kayu, } \\
\text { kaca) hasil dari pembentukan pola }\end{array}$ & 3 & 7 & 1 \\
\hline & $\mathrm{F} 23$ & $\begin{array}{l}\text { Kelilipan serbuk material (serbuk kayu, } \\
\text { kaca) hasil dari pembentukan pola }\end{array}$ & 3 & 7 & 2 \\
\hline \multirow[t]{4}{*}{ Pelubangan } & $\mathrm{F} 24$ & $\begin{array}{l}\text { Tangan terkena alat pelubang (mesin } \\
\text { bor) pada pelubangan material }\end{array}$ & 4 & 1 & 5 \\
\hline & $\mathrm{F} 25$ & $\begin{array}{l}\text { Terhirup serbuk material (serbuk kayu, } \\
\text { kaca) hasil dari pelubangan material }\end{array}$ & 3 & 7 & 1 \\
\hline & F26 & $\begin{array}{l}\text { Kelilipan serbuk material (serbuk kayu, } \\
\text { kaca) hasil dari pelubangan material }\end{array}$ & 3 & 7 & 1 \\
\hline & $\mathrm{F} 27$ & $\begin{array}{l}\text { Terkilir pada bagian tangan saat } \\
\text { pelubangan material }\end{array}$ & 3 & 2 & 3 \\
\hline \multirow{2}{*}{$\begin{array}{l}\text { Perakitan menjadi } \\
\text { produk jadi }\end{array}$} & F28 & Tangan terkena palu saat memaku & 2 & 8 & 2 \\
\hline & F29 & Tangan terkilir saat perakitan & 3 & 2 & 3 \\
\hline
\end{tabular}

Setelah mendapatkan nilai untuk masing-masing kriteria pada masing-masing variabel, langkah selanjutnya dihitung nilai RPN untuk masing-masing risiko kecelakaan dengan menggunakan persamaan 1 dan diurutkan sesuai nilai RPN dari yang tertinggi yang dapat dilihat pada Tabel 6.

Tabel 6. Hasil Perhitungan Risk Priority Number

\begin{tabular}{cccccccc}
\hline Ranking & F & S & O & D & RPN & \% Kumulatif & Tingkat Risiko \\
\hline 1 & F6 & 6 & 2 & 7 & 84 & 11.429 & Semi-Kritis \\
2 & F13 & 3 & 5 & 3 & 45 & 17.551 & Normal \\
3 & F23 & 3 & 7 & 2 & 42 & 23.265 & Normal \\
4 & F8 & 2 & 5 & 4 & 40 & 28.707 & Normal \\
5 & F1 & 4 & 8 & 1 & 32 & 33.061 & Normal \\
6 & F7 & 4 & 8 & 1 & 32 & 37.415 & Normal \\
7 & F19 & 2 & 4 & 4 & 32 & 41.769 & Normal \\
8 & F28 & 2 & 8 & 2 & 32 & 46.122 & Normal \\
9 & F4 & 3 & 2 & 5 & 30 & 50.204 & Normal \\
10 & F5 & 6 & 1 & 5 & 30 & 54.286 & Normal \\
11 & F11 & 3 & 7 & 1 & 21 & 57.143 & Normal \\
12 & F12 & 3 & 7 & 1 & 21 & 60.000 &
\end{tabular}




\begin{tabular}{cccccccc}
13 & F15 & 3 & 7 & 1 & 21 & 62.857 & Normal \\
14 & F16 & 3 & 7 & 1 & 21 & 65.714 & Normal \\
15 & F22 & 3 & 7 & 1 & 21 & 68.571 & Normal \\
16 & F25 & 3 & 7 & 1 & 21 & 71.429 & Normal \\
17 & F26 & 3 & 7 & 1 & 21 & 74.286 & Normal \\
18 & F24 & 4 & 1 & 5 & 20 & 77.007 & Normal \\
19 & F10 & 3 & 2 & 3 & 18 & 79.456 & Normal \\
20 & F17 & 3 & 2 & 3 & 18 & 81.905 & Normal \\
21 & F18 & 2 & 9 & 1 & 18 & 84.354 & Normal \\
22 & F20 & 3 & 2 & 3 & 18 & 86.803 & Normal \\
23 & F21 & 3 & 2 & 3 & 18 & 89.252 & Normal \\
24 & F27 & 3 & 2 & 3 & 18 & 91.701 & Normal \\
25 & F29 & 3 & 2 & 3 & 18 & 94.150 & Normal \\
26 & F14 & 4 & 4 & 1 & 16 & 96.327 & Normal \\
27 & F3 & 2 & 2 & 3 & 12 & 97.959 & Normal \\
28 & F9 & 1 & 9 & 1 & 9 & 99.184 & Normal \\
29 & F2 & 2 & 3 & 1 & 6 & 100.000 & Normal \\
\hline
\end{tabular}

Setelah mendapatkan nilai RPN untuk masingmasing risiko, langkah selanjutnya ditentukan $20 \%$ risiko kecelakaan proritas dengan menggunakan diagram pareto. Hasil dari prinsip pareto 80/20 ini adalah memperlihatkan risiko kecelakaan yang potensial dimana pada $80 \%$ permasalahan yang ada disebabkan oleh $20 \%$ penyebab. Diagram pareto membantu dalam memfokuskan untuk mengkaji $20 \%$ penyebab tersebut dibandingkan $80 \%$ penyebab lain yang hanya memiliki dampak kecil terhadap permasalahan yang ada. Risiko kecelakaan yang termasuk dalam $20 \%$ dampak terbesar dengan melihat nilai RPN akan dicari solusi alternatif untuk melakukan mitigasi risiko.

Pada urutan ranking di Tabel 6 sebelumnya terdapat nilai RPN yang sama sehingga dapat diurutkan terlebih dahulu yang memiliki nilai severity lebih tinggi dikarenakan kecelakaan yang lebih parah akan lebih diprioritaskan. Berikut ini merupakan penggambaran diagram pareto untuk risiko kecelakaan yang terjadi pada Mebel Abi Rodim yang dapat dilihat pada Gambar 2.

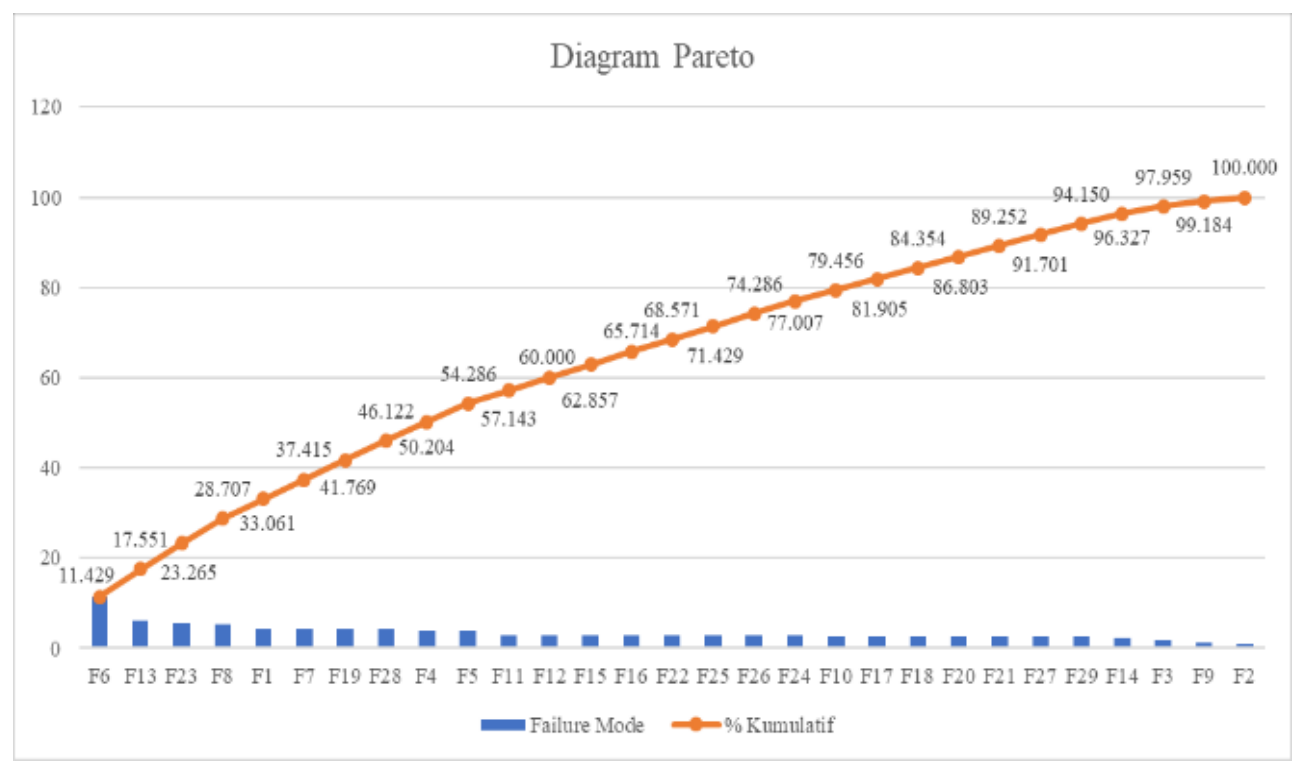

Gambar 2. Diagram Pareto Risiko Kecelakaan

Dari hasil pengolahan data dengan diagram pareto didapatkan $20 \%$ risiko kecelakaan proritas dimana terdapat enam risiko kecelakaan yang potensial yang masuk dalam $20 \%$ penyebab, yaitu sebagai berikut:

1. Jari terjepit kayu (risiko kecelakaan no. 6),

2. Terkilir pada bagian tangan saat pemotongan material (risiko kecelakaan no.13),

3. Kelilipan serbuk material (serbuk kayu, kaca) hasil dari pembentukan pola (risiko kecelakaan no. 23),
4. Tangan terkena alat pemotong (gergaji, gerinda) (risiko kecelakaan no.8),

5. Tangan terkena permukaan bahan yang masih kasar pada pengambilan material (kayu, kaca) (risiko kecelakaan no. 1), dan

6. Tangan terkena permukaan bahan baku yang masih kasar pada saat pemotongan material (risiko kecelakaan no.7). 
Dari hasil pengolahan data dengan diagram pareto didapatkan $20 \%$ risiko kecelakaan proritas. Langkah berikutnya dicari akar penyebab masalah dengan menggunakan diagram ishikawa. Berikut identifikasi penyebab masalah dari risiko kecelakaan potensial yang ada.

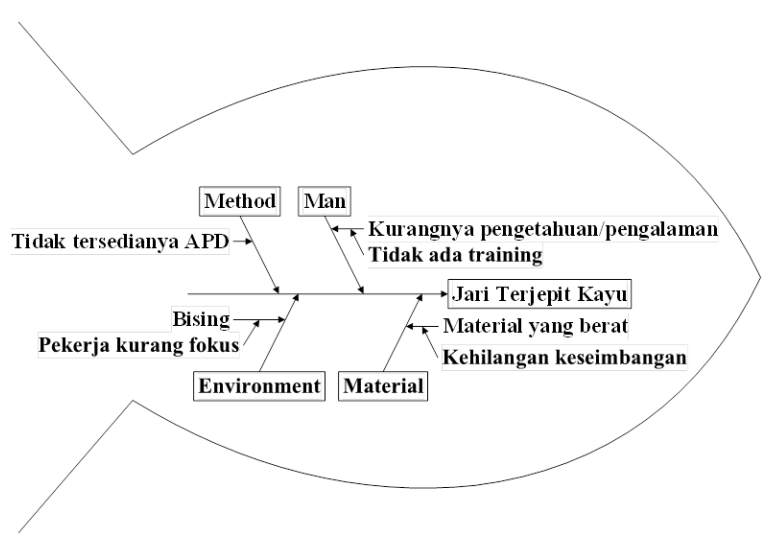

Gambar 3. Fishbone Risiko Kecelakaan No. 6

Berdasarkan Gambar 3, penyebab kecelakaan jari terjepit kayu diidentifikasi sebagai berikut:

1. Manusia (Man), masih kurangnya pengetahuan atau pengalaman pada proses pengambilan bahan baku sehingga tidak bisa mengangkut kayu dengan benar, kurangnya pengetahuan ini diakibatkan karena tidak adanya training pada pekerja terutama pekerja baru.

2. Metode (Method), belum tersedianya APD sehingga saat terjadi kecelakaan seperti jari terjepit kayu tidak bisa meminimalisir dampak yang diterima.

3. Material, material kayu yang terlalu berat mengakibatkan para pekerja yang mengangkut kayu (dengan tenaga manusia tanpa alat bantu) menjadi kehilangan keseimbangan.

4. Lingkungan (Environment), lingkungan yang bising bersumber dari mesin produksi di tempat bekerja membuat para pekerja menjadi tidak fokus.

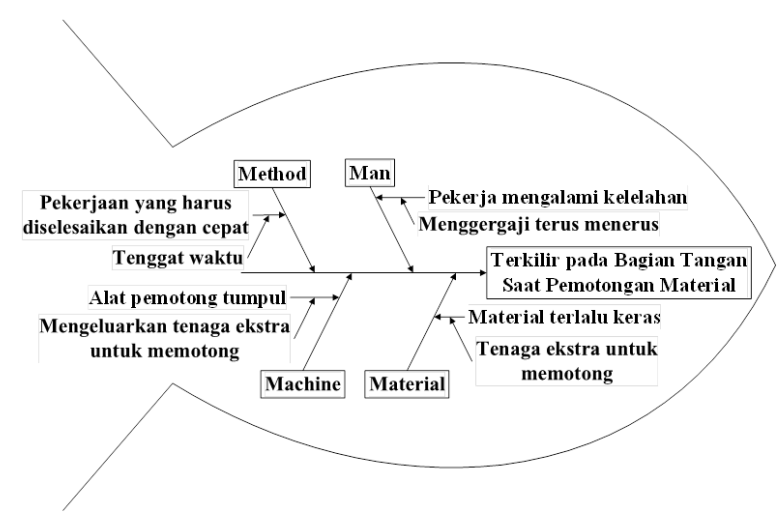

Gambar 4. Fishbone Risiko Kecelakaan No. 13
Berdasarkan Gambar 4, penyebab kecelakaan terkilir pada bagian tangan saat pemotongan material dapat diidentifikasi sebagai berikut:

1. Manusia (Man), pekerja mengalami kelelahan karena melakukan pekerjaan menggergaji secara terus menurus sehingga mengakibatkan terkilir pada bagian tangan, hal ini terjadi karena pekerja tidak memiliki waktu istirahat yang cukup dan tidak adanya sistem pergantian dalam melakukan pekerjaan tersebut.

2. Metode (Method), pekerjaan yang harus diselesaikan cepat karena terdapat tenggat waktu untuk menyelesaikannya membuat pekerja terburu-buru dalam melakukan pekerjaannya sehingga mengakibatkan terkilir pada bagian tangan, hal ini terjadi karena tidak adanya sistem pergantian ataupun waktu istirahat yang cukup.

3. Material, material kayu yang terlalu keras mengakibatkan para pekerja yang memotong kayu mengeluarkan tenaga lebih besar.

4. Mesin (Machine), mesin atau alat pemotong yang tumpul karena belum dilakukan persiapan sebelumnya mengakibatkan para pekerja yang memotong kayu memerlukan tenaga ekstra dalam pemotongannya.

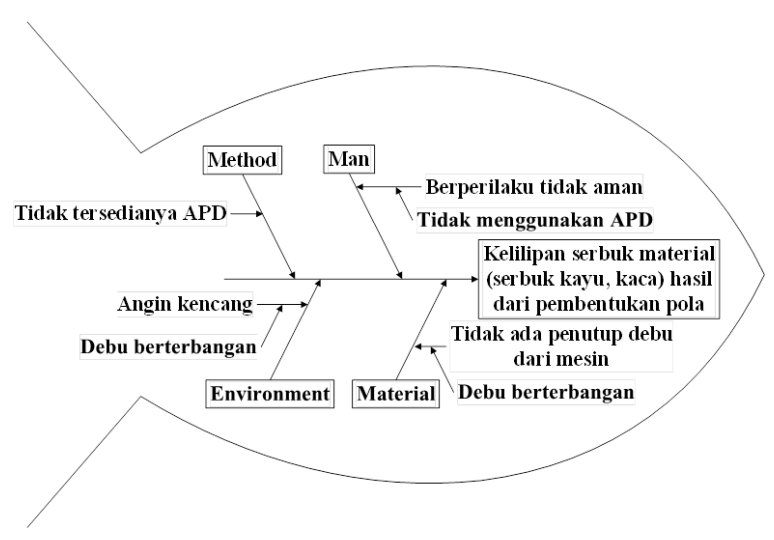

Gambar 5. Fishbone Risiko Kecelakaan No. 23

Berdasarkan Gambar 5, penyebab kecelakaan kelilipan serbuk material (serbuk kayu, kaca) hasil dari pembentukan pola dapat diidentifikasi sebagai berikut:

1. Manusia (Man), para pekerja berperilaku tidak aman pada saat bekerja, yaitu tidak menggunakan APD seperti kacamata untuk mengurangi risiko terkena serbuk material.

2. Metode (Method), belum tersedianya APD sehingga saat terjadi kecelakaan kelilipan serbuk material tidak bisa mengurangi risiko terkena serbuk material.

3. Mesin (Machine), pada mesin tidak terdapat penutup untuk debu keluaran dari mesin sehingga mengakibatkan debu yang dihasilkan menjadi berterbangan dan menjadi risiko mata terkena serbuk material. 
4. Lingkungan (Environment), pada lingkungan terdapat angin yang kencang mengakibatkan debu-debu menjadi berterbangan sehingga dapat membuat mata terkena serbuk material.

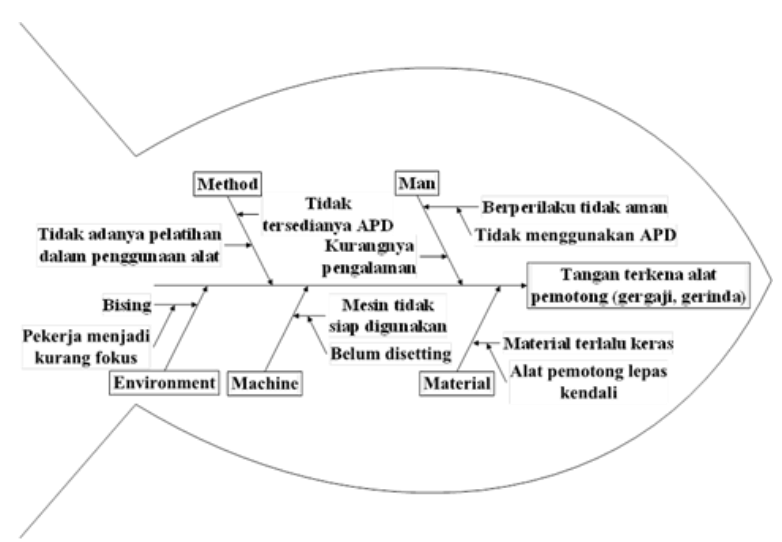

Gambar 6. Fishbone Risiko Kecelakaan No. 8

Berdasarkan Gambar 6, penyebab kecelakaan tangan terkena alat pemotong (gergaji, gerinda) dapat diidentifikasi sebagai berikut:

1. Manusia (Man), para pekerja berperilaku tidak aman pada saat bekerja, yaitu tidak menggunakan APD seperti sarung tangan untuk mengurangi dampak terkena alat pemotong, para pekerja juga masih terdapat yang kurang pengalaman dalam menggunakan alat pemotong.

2. Metode (Method), belum tersedianya APD sehingga saat terjadi kecelakaan terkena alat pemotong tidak bisa mengurangi dampak yang diterima dan tidak ada pelatihan dalam penggunaan alat pemotong sehingga para pekerja yang masih kurang pengetahuan atau pengalaman menjadi lebih mudah terkena risiko kecelakaan tersebut.

3. Material, material kayu yang terlalu keras mengakibatkan alat pemotong menjadi lepas kendali.

4. Mesin (Machine), mesin atau alat pemotong yang belum siap digunakan karena belum diasah atau belum disetting terlebih dahulu sebelum digunakan.

5. Lingkungan (Environment), lingkungan yang bersumber dari mesin produksi di tempat bekerja bising membuat para pekerja menjadi tidak fokus.

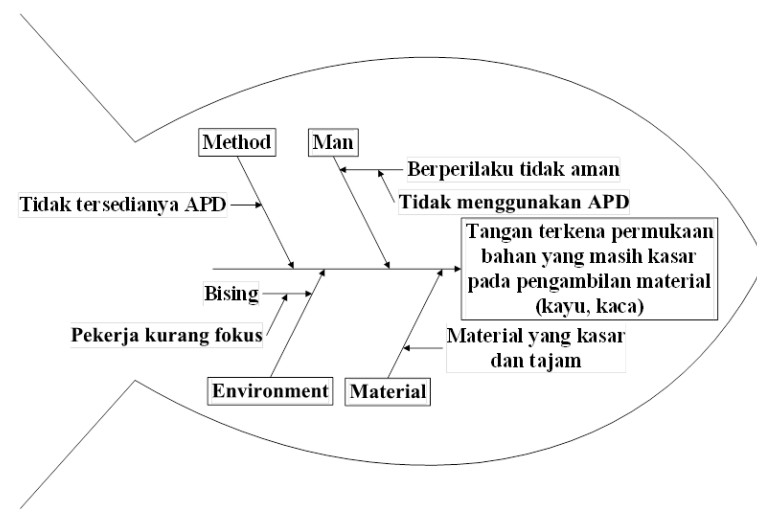

Gambar 7. Fishbone Risiko Kecelakaan No. 1

Berdasarkan Gambar 7, penyebab kecelakaan tangan terkena permukaan bahan yang masih kasar pada pengambilan material (kayu, kaca) dapat diidentifikasi sebagai berikut:

1. Manusia (Man), para pekerja berperilaku tidak aman pada saat bekerja, yaitu tidak menggunakan APD seperti sarung tangan untuk mengurangi dampak terkena permukaan yang masih kasar (serabut kayu, ujung kaca yang tajam, dan sebagainya).

2. Metode (Method), belum tersedianya APD sehingga saat terjadi risiko kecelakaan terkena permukaan bahan yang masih kasar tidak bisa mengurangi dampak yang diterima.

3. Material, material kayu dan kaca yang kasar dan tajam mengakibatkan tangan menjadi terluka.

4. Lingkungan (Environment), lingkungan yang bising bersumber dari mesin produksi di tempat bekerja membuat para pekerja menjadi kurang fokus saat memegang bahan.

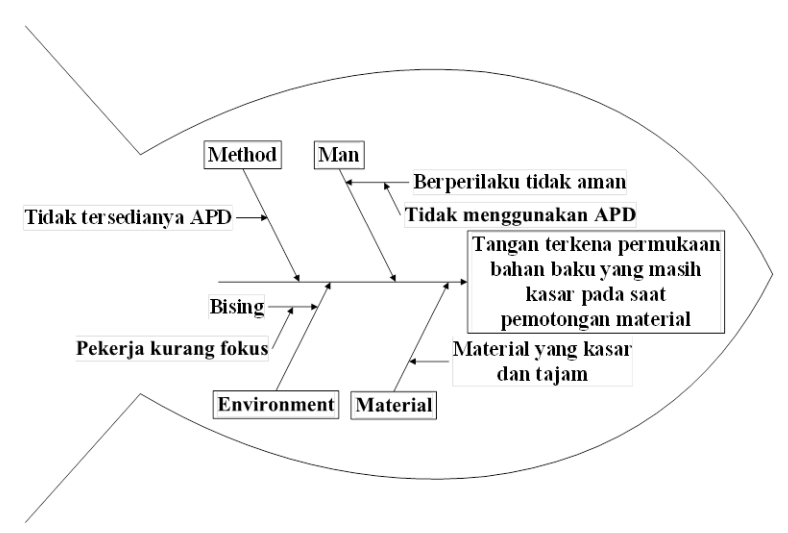

Gambar 8. Fishbone Risiko Kecelakaan No. 7

Berdasarkan Gambar 7, penyebab kecelakaan tangan terkena permukaan bahan baku yang masih kasar pada saat pemotongan material dapat diidentifikasi sebagai berikut:

1. Manusia (Man), para pekerja berperilaku tidak aman pada saat bekerja, yaitu tidak menggunakan APD seperti sarung tangan untuk mengurangi dampak terkena 
permukaan yang masih kasar (serabut kayu, ujung kaca yang tajam, dan sebagainya).

2. Metode (Method), belum tersedianya APD sehingga saat terjadi risiko kecelakaan terkena permukaan bahan yang masih kasar tidak bisa mengurangi dampak yang diterima.

3. Material, material kayu dan kaca yang kasar dan tajam mengakibatkan tangan menjadi terluka.

4. Lingkungan (Environment), lingkungan yang bising bersumber dari mesin produksi di tempat bekerja membuat para pekerja menjadi kurang fokus saat memegang bahan.

Hasil dari diagram Ishikawa tersebut merupakan solusi alternatif perbaikan untuk mitigasi risiko kecelakaan yang potensial. Berikut solusi alternatif perbaikan atau tindakan mitigasi risiko kecelakaan yang dapat diberikan.

1. Memberi pelatihan pada tiap karyawan,

2. Memberi SOP untuk penggunaan Alat Pelindung Diri (APD),

3. Menyediakan Alat Pelindung Diri (APD),

4. Mempersiapkan alat/mesin sebelum digunakan.

5. Memberi waktu istirahat yang cukup,

6. Menerapkan sistem shift (pergantian) pada karyawan, dan

7. Menambah karyawan.

Setelah mendapatkan opsi tindakan mitigasi risiko untuk risiko yang potensial lalu digunakan metode TOPSIS untuk menentukan mitigasi risiko terbaik atau solusi alternatif terbaik. Ditentukan terlebih dahulu kriteria untuk alternatif yang akan dipilih dengan BCOR (Benefit, Cost, Opportunity, dan Risk). Berikut penilaian yang digunakan untuk kriteria BCOR pada tiap alternatif yang dapat dilihat pada Tabel 7.

Tabel 7. Penilaian untuk Kriteria BCOR

\begin{tabular}{clc}
\hline \multicolumn{1}{c}{ Kriteria } & \multicolumn{1}{c}{ Tingkatan } & Rating \\
\hline Benefit (C1) & Sangat Baik & 5 \\
& Baik & 4 \\
& Cukup & 3 \\
& Buruk & 2 \\
Cost (C2) & Sangat Buruk & 1 \\
& Sangat Murah & 5 \\
& Murah & 4 \\
& Sedang & 3 \\
& Mahal & 2 \\
Opportunity (C3) & Sangat Mahal & 1 \\
& Sangat Siap & 5 \\
& Siap & 4 \\
& Cukup Siap & 3 \\
& Tidak Siap & 2 \\
& Sangat Tidak Siap & 1 \\
& Sangat Kecil & 5 \\
& Kecil & 4 \\
& Sedang & 3 \\
& Besar & 2 \\
& Sangat Besar & 1 \\
\hline & &
\end{tabular}

Opsi tindakan mitigasi risiko yang telah didapatkan kemudian dilakukan penilaian dengan kriteria BCOR sehingga didapatkan nilai BCOR untuk tiap mitigasi risiko atau solusi alternatif yang ada seperti pada Tabel 8 berikut:

Tabel 8. Penilaian untuk Kriteria BCOR

\begin{tabular}{|c|c|c|c|c|c|}
\hline & Mitigasi (Solusi Alternatif) & $\mathrm{C} 1$ & $\mathrm{C} 2$ & $\mathrm{C} 3$ & $\mathrm{C} 4$ \\
\hline A1 & $\begin{array}{l}\text { Memberi pelatihan pada tiap } \\
\text { karyawan }\end{array}$ & 4 & 3 & 3 & 3 \\
\hline A2 & $\begin{array}{l}\text { Memberi SOP untuk } \\
\text { penggunaan APD }\end{array}$ & 5 & 5 & 5 & 3 \\
\hline A3 & Menyediakan APD & 5 & 3 & 4 & 4 \\
\hline A4 & $\begin{array}{l}\text { Mempersiapkan alat/mesin } \\
\text { sebelum digunakan }\end{array}$ & 5 & 3 & 5 & 4 \\
\hline A5 & $\begin{array}{l}\text { Memberi waktu istirahat yang } \\
\text { cukup }\end{array}$ & 4 & 4 & 4 & 2 \\
\hline A6 & $\begin{array}{l}\text { Menerapkan sistem shift } \\
\text { (pergantian) pada karyawan }\end{array}$ & 3 & 2 & 1 & 1 \\
\hline A7 & Menambah karyawan & 3 & 1 & 1 & 1 \\
\hline
\end{tabular}

Langkah selanjutnya adalah melakukan perhitungan dengan metode TOPSIS, matriks perbandingan alternatif dengan kriteria ditunjukkan pada Tabel 8 yang kemudian akan dinormalisasikan menggunakan Persamaan 3 sehingga didapatkan hasil matriks yang ternormalisasi pada Tabel 9 sebagai berikut:

Tabel 9. Matriks Ternormalisasi

\begin{tabular}{ccccc}
\hline & C1 & C2 & C3 & C4 \\
\hline A1 & 0.358 & 0.351 & 0.311 & 0.401 \\
A2 & 0.447 & 0.585 & 0.518 & 0.401 \\
A3 & 0.447 & 0.351 & 0.415 & 0.535 \\
A4 & 0.447 & 0.351 & 0.518 & 0.535 \\
A5 & 0.358 & 0.468 & 0.415 & 0.267 \\
A6 & 0.268 & 0.234 & 0.104 & 0.134 \\
A7 & 0.268 & 0.117 & 0.104 & 0.134 \\
\hline
\end{tabular}

Kemudian dilakukan perhitungan bobot untuk masing-masing kriteria dengan menggunakan nilai entropi seperti pada Persamaan 4 dan Persamaan 5 sehingga didapatkan hasil bobot untuk setiap kriteria pada Tabel 10 sebagai berikut:

Tabel 10. Bobot Setiap Kriteria

\begin{tabular}{lc}
\hline \multicolumn{1}{c}{ Keterangan } & Bobot \\
\hline Benefit $(\mathrm{C} 1)$ & 0.351 \\
Cost $(\mathrm{C} 2)$ & 0.254 \\
Opportunity $(\mathrm{C} 3)$ & 0.182 \\
Risk $(\mathrm{C} 4)$ & 0.212 \\
\hline
\end{tabular}

Selanjutnya, ditetapkan solusi ideal positif $\left(\mathrm{v}^{+}\right)$ dan solusi ideal negatif $\left(\mathrm{v}^{-}\right)$untuk masing-masing kriteria dengan menggunakan Persamaan 6 dan Persamaan 7 sehingga didapatkan seperti Tabel 11 berikut:

Tabel 11. Nilai Solusi Ideal Positif dan Negatif

\begin{tabular}{ccccc}
\hline & C1 & C2 & C3 & C4 \\
\hline $\mathrm{v}^{+}$ & 0.447 & 0.585 & 0.518 & 0.535 \\
$\mathrm{v}^{-}$ & 0.268 & 0.117 & 0.104 & 0.134 \\
\hline
\end{tabular}


Kemudian, dihitung jarak pada setiap kriteria antara solusi ideal positif $(\mathrm{v}+)$ dan solusi ideal negatif (v-) dengan menggunakan Persamaan 8 dan Persamaan 9 serta dihitung relatif Risk Priority Index (RPI) berdasarkan jarak solusi ideal dengan menggunakan Persamaan 10. Alternatif yang memiliki nilai RPI tertinggi menunjukkan bahwa alternatif tersebut merupakan solusi alternatif terbaik yang ditentukan melalui metode TOPSIS. Berikut hasil perhitungan dari Risk Priority Index (RPI) pada Tabel 12.

Tabel 12. Hasil Perhitungan Risk Priority Index

\begin{tabular}{ccccc}
\hline Alternatif & $\mathrm{d}^{+}$ & $\mathrm{d}^{-}$ & RPI & Ranking \\
\hline $\mathrm{A} 1$ & 0.082 & 0.096 & 0.538 & 5 \\
$\mathrm{~A} 2$ & 0.028 & 0.164 & 0.853 & 1 \\
$\mathrm{~A} 3$ & 0.062 & 0.134 & 0.682 & 3 \\
$\mathrm{~A} 4$ & 0.060 & 0.143 & 0.706 & 2 \\
$\mathrm{~A} 5$ & 0.074 & 0.114 & 0.607 & 4 \\
$\mathrm{~A} 6$ & 0.158 & 0.030 & 0.159 & 6 \\
$\mathrm{~A} 7$ & 0.176 & 0 & 0 & 7 \\
\hline
\end{tabular}

Dari Tabel 10 didapatkan ranking untuk tiap alternative dimana A2 memiliki nilai RPI tertinggi sehingga berada pada peringkat 1 yang menunjukkan bahwa A2 atau solusi alternatif, yaitu memberi SOP untuk penggunaan Alat Pelindung Diri (APD) merupakan solusi alternatif terbaik yang dipilih untuk meminimalkan risiko kecelakaan potensial yang ada pada Mebel Abi Rodim.

\section{Kesimpulan}

Berdasarkan hasil penelitian, dapat disimpulkan bahwa diidentifikasi 29 risiko kecelakaan pada Mebel Abi Rodim. Dari 29 risiko kecelakaan tersebut terdapat enam risiko kecelakaan potensial yang masuk dalam $20 \%$ penyebab pada diagram pareto, yaitu jari terjepit kayu, terkilir pada bagian tangan saat pemotongan material, kelilipan serbuk material (serbuk kayu, kaca) hasil dari pembentukan pola, tangan terkena alat pemotong (gergaji, gerinda), tangan terkena permukaan bahan yang masih kasar pada pengambilan material (kayu, kaca), dan tangan terkena permukaan bahan baku yang masih kasar pada saat pemotongan material. Solusi alternatif perbaikan terbaik yang dapat diberikan adalah memberi SOP untuk penggunaan Alat Pelindung Diri (APD).

\section{Daftar Pustaka}

Casban. (2018). Analisis Penyebab Kecelakaan Kerja pada Proses Washing Container di Divisi Cleaning dengan Metode Fishbone Diagram dan SCAT. Jurnal Integrasi Sistem Industri, Vol. 5, No. 2, hal. 111-121.

Ebrahemzadih, M., Halvani, G.H., Shahmoradi, B., \& Giahi, O. (2014). Assessment and Risk Management of Potential Hazards by Failure Modes and Effect Analysis (FMEA) Method in
Yazd Steel Complex. Open Journal of Safety Science and Technology, Vol. 4, hal. 127-135

Galih, M., \& Rohana, S. (2014). Evaluasi Kemampuan dan Perhitungan Peringkat Siswa Menggunakan Metode TOPSIS dan Entropy. Jurnal Idaarah, Vol. II, No. 2, hal. 252-259.

Hendradewa, A.P., \& Ma'arij, A.M. (2021). Strategi Mitigasi Risiko Produktivitas pada Proses Assembly Hospital Equipment. Jurnal Media Teknik dan Sistem Industri, Vol. 5, No. 1, hal. 1724.

Maulidia, N., Suyeno, Muhsin, M. (2019). Analisis Benefit, Opportunity, Cost, dan Risk Program Pengembangan Karyawan pada The Harvest Malang. Jurnal Respon Publik, Vol. 13, No. 5, hal. 110-115.

Mustofa. (2014). Perencanaan Produktivitas Kerja dari Hasil Evaluasi Produktivitas dengan Metode Fishbone di Perusahaan Percetakan Kemasan PT. X. Jurnal Teknik Industri HEURISTIC, Vol. 11, No. 1, hal. 27-46.

Pasaribu, H.P., Setiawan, H., Ervianto, W.I. (2017). Metode Failure Mode and Effect Analysis (FMEA) dan Fault Tree Analysis (FTA) untuk Mengidentifikasi Potensi dan Penyebab Kecelakaan Kerja pada Proyek Gedung. S2 Thesis, UAJY.

Perdana, R.P., \& Yuliawati, E. (2014). Integrasi Metode FMEA dan TOPSIS Untuk Menganalisis Risiko Kecelakaan pada Proses Frame And Fork Welding. Spektrum Industri, Vol. 12, No. 1, hal. 1-112.

Putri, J.I., \& Ulkhaq, M.M. (2017). Identifikasi Bahaya dan Risiko pada Area Produksi CV Mebel Internasional, Semarang dengan Metode Job Safety Analysis. Industrial Engineering Online Journal, Vol. 6, No. 1.

Satriyo, B. \& Puspitasari, D. (2017). Analisis Pengendalian Kualitas dengan Menggunakan Metode Fault Tree Analysis untuk Meminimumkan Cacat pada Crank Bed di Lini Painting PT. Sarandi Karya Nugraha. Industrial Engineering Online Journal, Vol. 6, No. 1.

Sugiantara, K. \& Basuki, M. (2019). Identifikasi dan Mitigasi Risiko di Offshore Operation Facilities dengan Menggunakan Metode Failure Mode And Effect Analysis. Jurnal INTECH, Vol. 5, No. 2, hal. 87-92. 
